\title{
Accumulation of Heavy Metal Concentration and Physicochemical Parameters in Soil From Alice Landfill Site in Eastern Cape, South Africa
}

Nontobeko Gloria Maphuhla ( $\nabla$ maphuhlang@webmail.co.za )

University of Fort Hare Faculty of Science and Agriculture https://orcid.org/0000-0002-9887-5926

Francis Bayo Lewu

Cape Peninsula University of Technology

Opeoluwa Oyehan Oyedeji

University of Fort Hare Faculty of Science and Agriculture

\section{Research}

Keywords: Heavy metals, soil quality, accumulation, soil pollution, physicochemical parameters

Posted Date: June 29th, 2021

DOl: https://doi.org/10.21203/rs.3.rs-621824/v1

License: (c) (1) This work is licensed under a Creative Commons Attribution 4.0 International License.

Read Full License 


\section{Abstract}

Heavy metals are unique environmental and industrial pollutants scattered naturally and found almost in all phases of the environment. In certain limited areas in several parts of the world, many people and animals have suffered from several severe diseases caused by trace elements or heavy metal deficiencies and their toxicities, unaware of their existence. The compounds of $\mathrm{Pb}$ and $\mathrm{Cd}$ are classified as human carcinogens by numerous regulatory agencies. The soil samples digested using the aqua regia method, and concentration quantified through the Inductively coupled plasma mass spectrometry (ICPMS). In this study, $\mathrm{Pb}, \mathrm{Cd}$, and $\mathrm{Hg}$ concentrations were recorded high on the landfill site compared to the control site. Their concentration exceeded the permissible limits from WHO. Pb concentration ranges between $0.46 \mathrm{ppm}$ to $1.81 \mathrm{ppm}, \mathrm{Cd}$ range from $0.98 \mathrm{ppm}$ and $0.56 \mathrm{ppm}$, and $\mathrm{Hg}$ has a high concentration that varies between $6.28 \mathrm{ppm}$ and $1.69 \mathrm{ppm}$.

On the contrary, the Cu concentration reportable to be lesser than accepted WHO limits compared to the other two selected elements. The mean concentration of $\mathrm{Cu}$ ranges from $0.41 \mathrm{ppm}$ to $0.72 \mathrm{ppm}$. Soil pH for both sites ranged from slightly acidic (6.67) to neutral (7.09), which falls within the normal range suggested by WHO.

High $\mathrm{Hg}$ and $\mathrm{Pb}$ concentration in this study is a thing of concern. Undertaken this study to help address the soil pollution problem due to the illegal disposal of waste that results in metal accumulation.

\section{Introduction}

Soil is a very mixed heterogeneous medium, made up of solid stages (the soil matrix) containing organic matter, minerals, and fluid phases (the soil water and soil air), which are involved directly with each other as ions entering the soil system [1]. Soil serves as a sink and reservoir of metal contaminants from automobile emissions. It also functions as a natural buffer by controlling chemical elements and other environmental substances [2]. The soil quality depends on its natural composition and the anthropogenic activities caused by humans and management [3]. The contamination of soil through heavy metals has raised serious concerns in recent years regarding human health due to these metals' ability to accumulate in the environment and crop plantation. Humans could be affected by direct intake and food chain bioaccumulation [2].

Heavy metal pollution in a natural environment is a global and common problem because these metals are ineradicable, primarily if they exist in high percentages exceeding acceptable limits. Most of them are very dangerous and pose severe threats to all living organisms, including humans and plants. The concentration of heavy metals might come from vehicle exhaust since the site is situated not far from the gravel roads and tar roads from town to the surrounding areas. That results in many cars contribute to the increase of soil heavy metals [4]. The most common heavy metals are $\mathrm{Cd}, \mathrm{Pb}, \mathrm{Hg}, \mathrm{Cu}, \mathrm{Ni}, \mathrm{Cr}$, and $\mathrm{Fe}$. Some of these elements are important for all living organisms, such as $\mathrm{Zn}$ and Fe. 
In contrast, other elements like $\mathrm{Pb}, \mathrm{Hg}$, and $\mathrm{Cd}$ are dangerous in living organisms even if they are present in a small amount and can generate organ abnormalities in some living organisms [5]. For example, Zinc's required amount helps maintain both the metabolic and biochemical reactions of humans' bodies [6]. These metals are non-biodegradable and dangerous because of their potential to bio-accumulate in the environment. Heavy metals have a long persistent time through contact with soil components, and as a result, they enter the food chain through plants and animals [7].

The lack of modern remediation and the latest technologies to maintain landfill sites results in waste accumulation and subsequent interaction with soil and living organisms. For this reason, there are environmental and health implications [8]. In some cases, waste is cast-off recklessly regardless of their ecological consequences, while on dumpsites, burnt debris is left in the open, and ashes are abandoned at the sites [9]. It noted that people close to this dumpsite believe that the native fertility from a waste dumpsite is high; subsequently, they collect soil to use as compost and sometimes cultivate different crops on the dumpsite's temporarily abandoned plot. On the other hand, most people become heavy metal consumption victims due to insufficient information on heavy metal levels in dumpsites, leading to these consumers' death [8].

Heavy metals are among the most important parts of environmental pollution, utilizing long-term hazardous effects on soil ecosystems and negatively influencing biological processes in the soil. Hence there is a need for constant monitoring and regulation of their soil concentrations [10]. They commonly affect the growth, morphology, and metabolism of microorganisms, leading to decreased soil ecosystems' functional diversity [11].

A waste from municipal usually consists of papers, boxes, food waste, metal scraps, glasses, ceramics, and ashes. Improper collection and waste disposal have become one of the Alice community's most significant challenges every day. Some of the waste still exist in some streets despite its effort to clear them. In that case, the environment, people, and organisms are at high risk [5]. This study analyses the soil samples for their total heavy metal content in selected areas around the landfill site. Also, to evaluate the health risks posed by heavy metal pollution in soil and the effects of soil physicochemical properties on heavy metals transfer from the soil.

\section{Materials And Methods}

\subsection{Sites description}

The study was conducted in Alice Township under Raymond Mhlaba municipality, using two areas: the landfill site (site 1) located about $2 \mathrm{~km}$ outside Alice community and $\approx 3 \mathrm{~km}$ to the control site 2 (inside University of Fort Hare east campus). The dumpsite is situated among latitudes of $32^{\circ} 48^{\prime} 24.88^{\prime \prime S}$ and longitudes of $26^{\circ} 49^{\prime} 33.37^{\prime \prime} \mathrm{E}$, while the control site lies on the margins of $32^{\circ} 47^{\prime} 07.35^{\prime \prime} \mathrm{S}$ to $26^{\circ} 57^{\prime} 26.10^{\prime \prime} \mathrm{E}$ longitudes. 
Site 1 branched into three portions: portion A (east side) got lots of broken glasses. In contrast, portion B (south side) was dominated by rusted tins and broken glasses with evidence of burnt waste, and portion $C$ was situated outside the landfill site fence only occupied by natural vegetation. Site 2 is an undisturbed land with its soil surface covered by natural vegetation and located near hills.

\subsection{1 collection and preparation of samples}

The soil samples were randomly collected at a depth of $0-25 \mathrm{~cm}$ twice per week for six weeks (April to mid-May). A clean soil auger utilized in soil sampling at each portion of Site 1, and uncontaminated soils were collected from Site 2. Sampled dry soil was contained and transported to the laboratory for advanced examination. The ground soils are sieved through a $2 \mathrm{~mm}$ mesh sieve to remove unwanted debris. The homogenized soils kept at room temperature to be analyzed further.

\subsection{Physicochemical properties}

\section{Moisture content}

In a beaker of known mass, the soil samples were added and measured the mass. The soils were then oven-dried for 24 hours at $105^{\circ} \mathrm{C}$ until the constant weight obtained after heating samples were cooled in a desiccator and placed in a clean plastic bag for further analysis [7].

Calculation:

$$
\text { Mass } \%=\left(\frac{\text { Air dried }- \text { Oven dried }}{\text { oven dried }}\right) \times 100 \%
$$

\section{Soil pH}

The soil pH was measured using a 1:2.5 ratio (soil: water by volume), where $5.0 \mathrm{~g}$ of sieved soil was delivered to a beaker containing $12.5 \mathrm{~mL}$ of deionized water and mixed well. Soil $\mathrm{pH}$ value is read by immersing a hand-held glass electrode $\mathrm{pH}$ meter into the partially settled solution, making sure the electrode doesn't touch the walls of the beaker [2].

\section{Soil electrical conductivity (E.C.)}

$5.0 \mathrm{~g}$ of homogenized soil samples were added to a beaker and mixed with $10 \mathrm{~mL}$ of double-distilled water. The content was shaken intermittently for 5 minutes and allowed to settle for 5 minutes. The E.C. probe curved into the solution to measure the electrical conductivity [12].

\section{Soil Organic Matter (SOM)}


In a $250 \mathrm{~mL}$ conical flask, $1.0 \mathrm{~g}$ of soil sample with $10 \mathrm{~mL} \mathrm{~K} \mathrm{Cr}_{2} \mathrm{O}_{7}$ were mixed, and the flask swirled gently to dissolve the soil. $20 \mathrm{~mL}$ of concentrated $\mathrm{H}_{2} \mathrm{SO}_{4}$ has quickly added to the solution in the mixture, allowed to stand on a fume hood for 30 minutes to cool down. After that, $200 \mathrm{~mL}$ of distilled water added, and the formed suspension was filtered using a filter paper. 3-5 drops of ferroin indicator added, and the solution titrated with $\mathrm{FeSO}_{4}$. The end is reached when the solution changes from dark green to blue to reddish-brown $[13,14]$.

$$
\text { Organic matter }(\%)=\left[M \times\left(\frac{V 1-V 2}{\text { Mass of the soil }}\right) \times 0.39\right] \times 1.724
$$

Where $M=$ concentration of $\mathrm{FeSO}_{4}, \mathrm{~V} 1=$ Volume of blank, $\mathrm{V} 2=$ Volume of $\mathrm{FeSO}_{4}, 0.39=$ constant, $1.724=$ constant

\subsection{Heavy metals in soil}

\section{Sample digestion}

$1.0 \mathrm{~g}$ of well-mixed soil samples were digested in a hotplate using $20 \mathrm{~mL}$ concentrated $\mathrm{HNO}_{3}$. The digested mixture in a conical flask was heated until the solution was reduced to $5 \mathrm{~mL}$, after which $20 \mathrm{~mL}$ of distilled water was added and heated until the suspension decreased to $10 \mathrm{~mL}$. When digestion finished, the residue was set aside to cool at room temperature and filtered using Whatman filter paper and make up to $50 \mathrm{~mL}$ volumetric flask with distilled water [5]. The heavy metal concentration analysis was quantified using Inductively coupled plasma mass spectrometry (ICP-MS) [7]. The data was analyzed using SPSS 26, version 26.0. Tukey Post-hoc tests at $p \leq 0.05$ for multiple comparisons of means from one-way ANOVA and the significant difference among the selected enzyme activity means. IBM Pearson's correlation will be used to analyze the relationships between the groups. This study was approved for ethical clearance by AREC University of Fort Hare, with certificate number: OYE021SMAP01/19/E.

\section{Results}

\subsection{Soil physicochemical parameters}

Table 1 presents the soil's physicochemical properties in the landfill site and the control site.

$\mathrm{pH}$ : The mean concentration of hydrogen ions $(\mathrm{pH})$ in all soil samples range from slightly acidic conditions $(6.79 \pm 0.28)$ to neutral soils $(7.09 \pm 0.37)$. The results revealed that the soil's $\mathrm{pH}$ in landfill sites stretched from slightly acidic to a neutral soil $\mathrm{pH}$, whereas in the control site, the $\mathrm{pH}$ concentration is slightly acidic $(6.67 \pm 0.28)$.

This study indicated that all collected soil samples from both sites are within the standard $\mathrm{pH}$ range set by WHO (6.5 to 8.5). The variation of soil pH might attribute to the topography effects, such as soils on the side of hills, which tend to be shallow due to erosional losses [15]. Also, dry environments may lead to 
various soil $\mathrm{pH}$, where leaching and weathering are less intense, resulting in neutral and sometimes alkaline soils.

Moisture content: Soil moisture is an essential variable in the climate system. The moisture content is higher in landfill site when compared to control site soils, the mean values of moisture content on Site 1 ranges between $(11.07 \pm 3.39 \%)$ and $(13.48 \pm 3.43 \%)$, while in Site 2 , the mean weight percentage was $10.16 \pm 2.30 \%$ respectively. The low levels of moisture in both sites may be due to these sites' topography, controlling water flow and material transport. Sites 1 and 2 were both located on hill slopes, with area 2 hillier than site A. There was a significant difference between all site A and site B portions. This topography type is likely to encourage quick rainwater runoff during rainy days before the soil could absorb enough water and dry soils. Warm weather with less rain during sampling days is also contributing to a high evaporation rate of soil moisture and the resultant dry soil observed in this study.

Soil electrical conductivity (E.C.): The electrical conductivity concentration range between $606 \pm 349.87$ $\mu \mathrm{S} / \mathrm{cm}$ and $72.04 \pm 41.59 \mu \mathrm{S} / \mathrm{cm}$. The high content of electrical conductivity practical on portion A of Site 1 , followed by the control site's soils (Site 2 ) and the minimum values reported on portion $B$ soils. The E.C.'s obtained data in this study is well below the earth's salinity threshold. Soil E.C. is a significant indicator of soil salinity, and it is a measure of the amount of salt in the soil but does not indicate the specific salt or ions that might be present. E.C. is a good indicator of salts like sodium, potassium, chloride, or sulfate [16]. Saline soils are those with salt levels (E.C.) above $4 \mathrm{dS} / \mathrm{m}$ [17]. In the present study, the soil's E.C. indicates to be lower than the saline level.

Soil E.C. lower than $200 \mu \mathrm{S} / \mathrm{cm}$ has insufficient nutrients for the plants and could show a disinfected soil with little microbial activity [18].

Soil Organic matter (SOM): Organic matter means the percentage noted to range between $1.62 \pm 0.93 \%$ and $0.96 \pm 0.55 \%$. In all sites, organic matter existed in meager amounts at a rate of $<2 \%$, with the least moderate values of $1.62 \%$ observed at portion B of Site 1 and a low percentage of 0.96 reported on portion $\mathrm{C}$ soils. This study's low organic matter levels may be caused by decaying microorganisms' reduced existence since organic matter is considered an essential soil health component. Therefore, its reduction results in soil degradation, increasing the decomposition rate and low availability of soil vegetation. Soil organic matter is the most valuable soil property. Low and poor organic matter levels may increase soil erosion processes, while the high amount of organic matter could affect the soil pH by decreasing soil pH levels [19]. Soil organic matter improves both the soil's physical and chemical properties by promoting biological activity and maintaining environmental quality [20]. It is also known to play a significant role in providing nutrients and water to plants and giving a good state of plants [21].

Table 1: Physiochemical properties in soil (Mean \pm SD)

Data presented as the mean, $n=3 ;$ S.D. = Standard Deviation; Means with different letters within the same column show a significant difference $(P<0.05)$. Letter $a, b, c$, and $d$ in the means show that there is a statistically significant difference between the variables in the column 


\begin{tabular}{|c|c|c|c|c|}
\hline $\begin{array}{l}\text { Sample } \\
\text { Sites }\end{array}$ & Moisture content (\%) & $\mathrm{pH}$ & $\begin{array}{l}\text { Electrical } \\
\text { Conductivity }(\mu \mathrm{s} / \mathrm{cm})\end{array}$ & $\begin{array}{l}\text { Organic } \\
\text { Matter (\%) }\end{array}$ \\
\hline \multirow{2}{*}{$\begin{array}{l}\text { Site1- } \\
\text { Portion A }\end{array}$} & $12.30 \pm 1.89 a$ & \multirow{2}{*}{$\begin{array}{l}7.06 \pm \\
0.22 a\end{array}$} & $606 \pm 349.87 a$ & $1.40 \pm 0.80 a$ \\
\hline & $13.48 \pm 3.43 b$ & & $72.04 \pm 41.59 b$ & $1.62 \pm 0.93 a$ \\
\hline $\begin{array}{l}\text { Site1- } \\
\text { Portion B }\end{array}$ & $11.07 \pm 3.39 c$ & $\begin{array}{l}7.09 \pm \\
0.37 a\end{array}$ & $264 \pm 152.42 c$ & $0.96 \pm 0.55 b$ \\
\hline $\begin{array}{l}\text { Site1- } \\
\text { Portion C }\end{array}$ & $10.16 \pm 2.30 d$ & $\begin{array}{l}6.79 \pm \\
0.25 b\end{array}$ & $133.01 \pm 76.79 d$ & $1.16 \pm 0.67 c$ \\
\hline $\begin{array}{l}\text { Site } 2 \\
\text { (control) }\end{array}$ & & $\begin{array}{l}6.67 \\
\pm 0.28 b\end{array}$ & & \\
\hline
\end{tabular}

\subsection{Heavy metals in soil}

Table 2 shows the predominating elements $(\mathrm{Pb}, \mathrm{Cd}, \mathrm{Cu}$, and $\mathrm{Hg}$ ) results in this study. Heavy metal concentration for soil samples are in ppm, and Figure 2 provides a graphical form of results

\section{Lead $(P b)$ :}

Lead $(\mathrm{Pb})$ 's mean concentration in this study exceeded the permissible limits from WHO $(0.10 \mathrm{ppm})$ for all portions of Site 1 and Site 2 soils. The highest deposit of $\mathrm{Pb}(1.81 \pm 1.05 \mathrm{ppm})$ at landfill site (Site 1portion $A)$ followed by the soil from portion $B(1.04 \pm 0.06 \mathrm{ppm})$ while the control site (Site 2$)$ soils carried the lowest $\mathrm{Pb}$ deposits $0.46 \pm 0.60 \mathrm{ppm}$. The results reveal that the polluted soils from landfill sites hold a high $\mathrm{Pb}$ concentration than the soils from unpolluted sites. Lead $\mathrm{Pb})$ is a metal associated with human activities for several decades, and it is a common industrial metal that had become widespread in soil, air, and water. High $\mathrm{Pb}$ concentration in the dumpsites soil might be due to large deposits of used batteries, used plastics materials, lubrication oils, and automobile exhaust fumes. Areas next to the roads and in the drip lines of older housing usually contain a high $\mathrm{Pb}$ number [22].

Exposure to high $\mathrm{Pb}$ levels can cause a range of health problems such as chronic neurological disorders, especially in fetuses and children. Since they are still small, their bodies continue to grow [23]. The most common sources of $\mathrm{Pb}$ that might result in more $\mathrm{Pb}$ concentration in site $\mathrm{B}$ are deteriorated paint in older housing and suspended soil dust [22].

\section{Cadmium (Cd):}

Cadmium (Cd) has higher concentration levels at Site1-portion C $(0.98 \pm 0.89 \mathrm{ppm})$, while the lowest amounts procure at Site1-portion B $(0.56 \pm 0.41 \mathrm{ppm})$. The Cd levels existed in amounts way above WHO permissible limits for Site 1 and Site 2. Cd exists naturally, and it's a poisonous heavy metal that can occur as a waste product from industrial workplaces, plant soils, and smoking. The high levels may occur due to the disposal of cadmium batteries or metal scraps and metal plating, plastic stabilizers, and pesticides. It is also present as a pollutant in phosphate fertilizers, and some cigarette smoking can be a significant source of Cd exposure. People can have kidney failure as Cd exposure results [24]. Cd 
concentration has the potential to contaminate the soil at just one point. It has been noted to impact human health as it has long-term bioaccumulation, causes renal dysfunction, lung cancer, and bone defects [25].

\section{Copper (Cu):}

This metal deposit was higher on control site soils $(0.72 \pm 0.40 \mathrm{ppm})$ than on portions of Site 1 , while soils of portion B of Site 1 carry shallow $\mathrm{Cu}$ concentration. Their concentration ranges between $0.72 \pm$ $0.40 \mathrm{ppm}$ and $0.41 \pm 0.15 \mathrm{ppm}$. The obtained results reveal that unpolluted soils contain higher $\mathrm{Cu}$ concentrations than polluted soils. For this study, $\mathrm{Cu}$ concentration was available below the allowed limit value from $\mathrm{WHO}$, and the values were recorded less than $<1.50$.

Copper is a critical element for different metabolic processes. It occurs naturally and spreads through the environment. The $\mathrm{Cu}$ can be free into the location through natural sources and human activities. The application of fertilizers, pesticides, and fungicides that contain copper might cause high levels of $\mathrm{Cu}$ in the soil. Also, the solubility of $\mathrm{Cu}$ decreases with the increases in soil pH [26].

Long-term $\mathrm{Cu}$ exposure can result in irritation of the nose, mouth, and eyes. Sometimes it can cause headaches, stomach aches, dizziness, vomiting, and diarrhea. Furthermore, high uptakes of $\mathrm{Cu}$ substances may lead to liver and kidney damage and death [27].

The soil contamination by $\mathrm{Cu}$ resulting from excessive $\mathrm{Cu}$ concentration has health risks that could bring about infections, anaemia, and thinning of bones [28]. Lead, copper, and Cadmium combine with the sulfhydryl (-S.H.) group, interfering with the other substances' enzymes in the body. Also, they inhibit the passage of nutrients in and out of the cell [5].

\section{$\operatorname{Mercury}(\mathrm{Hg})$ :}

The mercury $(\mathrm{Hg})$ concentration ranges between $6.28 \pm 4.21 \mathrm{ppm}$ and $1.69 \pm 0.62 \mathrm{ppm}$. High $\mathrm{Hg}$ concentrations were reported on Site 1 portions, while on Site 2, soils contain small amounts. The mean concentrations of $\mathrm{Hg}$ for all collected soil were exceedingly above the WHO's approved limit.

WHO allows $1.0 \mathrm{mg} / \mathrm{kg}$ respectively as the maximum permissible limits of $\mathrm{Hg}$ on soil [29]. In South Africa, the allowable soil limit for $\mathrm{Hg}$ is $0.93 \mathrm{mg} / \mathrm{kg}$ [30].

Table 2: The mean concentration of selected heavy metals in the soils of the study sites (mean \pm S.D.) 
Mean concentration (ppm)

\begin{tabular}{|c|c|c|c|c|c|}
\hline $\begin{array}{l}\text { Collection } \\
\text { sites }\end{array}$ & $\mathrm{Pb}$ & $\mathrm{Cd}$ & $\mathrm{Cu}$ & $\mathrm{Hg}$ & $\begin{array}{l}\text { Permissible limits [23] from } \\
\text { WHO (ppm) }\end{array}$ \\
\hline $\begin{array}{l}\text { Site 1- } \\
\text { portion A }\end{array}$ & $\begin{array}{l}1.81 \pm \\
1.05 a\end{array}$ & $\begin{array}{l}0.63 \pm \\
0.54 a\end{array}$ & $\begin{array}{l}0.63 \pm \\
0.41 a\end{array}$ & $\begin{array}{l}6.28 \pm \\
4.21 a\end{array}$ & $\mathrm{~Pb}: 0.10$ \\
\hline $\begin{array}{l}\text { Site 1- } \\
\text { portion B }\end{array}$ & $\begin{array}{l}1.04 \pm \\
0.05 b\end{array}$ & $\begin{array}{l}0.56 \pm \\
0.41 a\end{array}$ & $\begin{array}{l}0.41 \pm \\
0.14 b\end{array}$ & $\begin{array}{l}3.53 \pm \\
1.98 b\end{array}$ & Cd: 0.01 \\
\hline $\begin{array}{l}\text { Site 1- } \\
\text { portion C }\end{array}$ & $\begin{array}{l}0.80 \pm \\
0.41 \mathrm{~b}\end{array}$ & $\begin{array}{l}0.98 \pm \\
0.89 b\end{array}$ & $\begin{array}{l}0.51 \\
\pm 0.15 c\end{array}$ & $\begin{array}{l}3.21 \pm \\
2.30 c\end{array}$ & Cu: 1.50 \\
\hline $\begin{array}{l}\text { Site } 2 \\
\text { (control) }\end{array}$ & $\begin{array}{l}0.46 \pm \\
0.60 c\end{array}$ & $\begin{array}{l}0.84 \pm \\
0.45 c\end{array}$ & $\begin{array}{l}0.72 \pm \\
0.40 d\end{array}$ & $\begin{array}{l}1.69 \pm \\
0.62 d\end{array}$ & $\mathrm{Hg}: 1.0$ \\
\hline
\end{tabular}

Data presented as the mean, $n=3$; S.D. = Standard Deviation, means with different letters within the same column shows a significant difference $(P<0.05)$

\subsection{Statistical results}

The one-way ANOVA statistical analysis and Correlation examination results are shown in Table 3 and Table 4, respectively.

A statistically significant difference between groups was determined by one-way ANOVA ( $F=8.443 ; p=$ 0.003 ). A Tukey post hoc test revealed that the heavy metal concentration significantly different from one metal content to another.

The multiple comparisons show that the concentration of $\mathrm{Pb}, \mathrm{Cu}$, and $\mathrm{Cd}$ is not statistically different where $\mathrm{p}>0.05$, while the concentration of $\mathrm{Hg}$ was statistically different from concentration $\mathrm{Pb}, \mathrm{Cu}, \mathrm{Cd}$ where $p<0.05$.

Lead $(P b)$ : There is a statistically significant difference between the sample sites observed for concentration of $\mathrm{Pb}$ metal in soil samples, determine by ANOVA $(\mathrm{F}=8.443 ; \mathrm{p}=0.003)$. The $\mathrm{Pb}$ concentration on all portions of Site 1 soils contains more $\mathrm{Pb}$ concentration than the soils of Site 2 (control sites). This data is proved by the significance level, which is more than $0.05(p>0.05)$. The $\mathrm{Pb}$ concentration (presented in Table 4) negatively correlated with the concentration of $\mathrm{Cd}$ and $\mathrm{Cu}$, while the correlation between $\mathrm{Pb}$ and $\mathrm{Hg}$ is significantly positive. $\mathrm{Pb}$ correlated positively but non-significantly with soil pH levels, moisture content, electrical conductivity, and organic matter.

Cadmium (Cd): ANOVA results for $\mathrm{Cd}$ show a statistically significant difference between the $\mathrm{Cd}$ concentrations in soils of Site 1 and Site 2 , with the probability value $(F=8.443 ; p=0.003)$. That means Site 1 and Site 2 soil samples have a significant difference in their concentration. It also suggests that variability in Site 1 and Site 2 is not the same. They differ much more in concentration, and we are 95\% confident that the difference between the means of these two sites is not due to chance. The null hypothesis is rejected because the $p$-value is less than $0.05(p<0.05)$. Cd concentration (as shown in 
Table 4) correlated non-significantly negative with $\mathrm{Hg}$ concentration, and the correlations were positive between $\mathrm{Cd}$ and $\mathrm{Cu}$. The concentration of $\mathrm{Cd}$ correlated negatively with levels of soil $\mathrm{pH}$, moisture content, electrical conductivity, except for organic matter content, which significantly correlated with $\mathrm{Cd}$ at 0.05 level.

Mercury $(\mathrm{Hg})$ : A one-way between soil samples of two sites, ANOVA was conducted to compare $\mathrm{Hg}$ concentrations within these sites. There was a statistically significant difference in $\mathrm{Hg}$ concentration between soils of Site 1 and Site 2 at the $p<0.05$ level for the conditions $F=8.443 ; p=0.003$. A negatively non-significant correlation has been experimented with $\mathrm{Hg}$ concentration and $\mathrm{Cu}$, but $\mathrm{Hg}$ concentration correlated significantly positively with soil $\mathrm{pH}$, moisture content, electrical conductivity, and organic matter.

Copper ( $\mathrm{Cu}$ ): The calculated one-way analysis of variance (ANOVA) on soil samples of polluted and unpolluted sites reveals a statistically significant difference between the two sites for $\mathrm{Cu}$ concentration, $F=8.443 ; p=0.003$. This data suggests a significant difference between the mean $\mathrm{Cu}$ concentration on two Sites (1 and 2). Cu concentration correlated negatively with $\mathrm{pH}$, moisture content, organic matter, except for electrical conductivity, which correlated positively but non-significantly with Cu concentration.

These results indicate that physicochemical properties directly impact the concentration level of selected metals, except for $\mathrm{Cd}$, which is indirectly affected by physicochemical parameters.

Table 3: The one-way ANOVA results in the analysis of four ubiquitous metals in soil samples.

\begin{tabular}{|lllllll|}
\hline ANOVA & & & & & \\
\hline Metals & & & & & \\
\hline & Sum of Squares & df & Mean Square & F & Sig. \\
\hline Between Groups & 25.543 & 3 & 8.514 & 8.443 & 0.003 \\
\hline Within Groups & 12.102 & 12 & 1.009 & & \\
\hline Total & 37.646 & 15 & & & \\
\hline
\end{tabular}

Table 4: The correlation analysis between heavy metals and soil physicochemical properties 


\begin{tabular}{|c|c|c|c|c|c|c|c|c|}
\hline & $\mathrm{Pb}$ & $\mathrm{Cd}$ & $\mathrm{Hg}$ & $\mathrm{Cu}$ & $\mathrm{pH}$ & $\begin{array}{l}\text { Moisture } \\
\text { content }\end{array}$ & $\mathrm{OM}$ & EC \\
\hline $\mathrm{Pb}$ & 1 & & & & & & & \\
\hline $\mathrm{Cd}$ & -0.603 & 1 & & & & & & \\
\hline $\mathrm{Hg}$ & $0.994^{* *}$ & -0.516 & 1 & & & & & \\
\hline $\mathrm{Cu}$ & -0.110 & 0.275 & -0.121 & 1 & & & & \\
\hline $\mathrm{pH}$ & 0.799 & -0.853 & 0.761 & -0.576 & 1 & & & \\
\hline $\begin{array}{l}\text { Moisture } \\
\text { content }\end{array}$ & 0.603 & -0.829 & 0.561 & -0.741 & $0.961^{*}$ & 1 & & \\
\hline $\mathrm{OM}$ & 0.485 & $-0.986^{*}$ & 0.395 & -0.375 & 0.829 & 0.853 & 1 & \\
\hline EC & 0.829 & -0.119 & 0.861 & 0.314 & 0.328 & 0.062 & -0.042 & 1 \\
\hline
\end{tabular}

** Correlation is significant at 0.01 level (2-tailed)

${ }^{*}$ Correlation is significant at 0.05 level (2-tailed)

\section{Discussion}

The examined soil samples were moderately acidic to neutral and showing mean $\mathrm{pH}$ values from 6.67 to 7.09. At the same time, organic matter occurred at a low percentage $<2 \%$, and electrical conductivity results show that the collected soils are non-saline. Soil pH and other soil properties are significant in soil processes responsible for heavy metals' solubility in soil and transportation [31]. At low pH, metals tend to be found as free ionic species or soluble organometals and are more bioavailable. Since low $\mathrm{pH}$ (acidic) metals are more soluble and more bioavailable in the soil solution, the range of $\mathrm{pH}$ values obtained in this study will favour plant uptake of heavy metal. Hence, toxicity problems are possible. The moderately acidic soil from the control site may rise in micronutrient solubility and mobility and significantly heavy metal concentration in the soil [32].

Salman et al. 2019 reported similar findings on soil pH, resulting from low rainfall in the area. The soil organic matter flocculated from below detected limits to average content of $0.76 \%$. More than $82 \%$ of these metals $\mathrm{Cu}, \mathrm{Pb}$, and $\mathrm{Cr}$ reported below the upper critical limit, while $\mathrm{Cd}$ exceeded the allowable limits [33]. Another study said the soil pH ranged between 4.48 and 7.38. organic matter content observed from $1.59-3.36 \%$. The obtained results indicate that $\mathrm{Pb}, \mathrm{Ni}$, and $\mathrm{Cu}$ levels were comparable and showed that these metals come from an inherent heterogeneity pattern. While $\mathrm{Cd}$ and $\mathrm{Zn}$ concentrations occurred more than the allowable standard values. The results show that different pollution point sources might exist in the sites [34]. 
This study's obtained results reveal that the soil is strongly contaminated by lead, cadmium, mercury, and copper. Their accumulation concentration order in the ground is as follows $\mathrm{Hg}>\mathrm{Pb}>\mathrm{Cd}>\mathrm{Cu}$. Four heavy metals identified to be predominating in this study are $\mathrm{Pb}, \mathrm{Hg}, \mathrm{Cd}$, and $\mathrm{Cu}$, with $\mathrm{Hg}, \mathrm{Pb}$, and $\mathrm{Cd}$ exceeding the WHO's allowable limits.

Similar conclusions were also reached by Demkova et al. 2017 and agreed with this study's findings. They found that $\mathrm{Hg}, \mathrm{Cd}$, and $\mathrm{Zn}$ exceeded the acceptable limit values in all sampling sites. The high contamination level of heavy metals in soil shows their persistence and non-biodegradability characteristics. The site(mine) used for the study after the 21 st century was no longer active operations [35]. Comparable findings to our research by He et al. 2020 noted the lead (Pb) and Cd average concentrations amidst all agricultural soil samples to be higher. They exceeded the acceptable standard values, while Cu concentrations varied within the sites, respectively [36].

A detailed study by Malkoc 2010 reported a different result. They stated no mercury (Hg) was discovered in their soil samples, while the concentration of other metals, the $\mathrm{Cu}, \mathrm{Cr}, \mathrm{Cd}, \mathrm{Fe}$, $\mathrm{Ni}$, and $\mathrm{Mn}$, were recorded on elevated amounts. The high concentration of $\mathrm{Cu}, \mathrm{Pb}$, and $\mathrm{Zn}$ pollution on soil shows metals' sources come from automobile traffic [37].

Copper intake in plant species may increase when $\mathrm{pH}$ and organic fertilizers are low in the soil. Cu is one of the essential elements for all life forms but becomes toxic when it is available in large quantities. Lead concentration may occur due to fuel combustion residues accumulation from transportation and pesticides. $\mathrm{Pb}$ concentration is associated with organic matter colloidal in soil, which results in more $\mathrm{Pb}$ proportion. Pb may cause chronic emphysema because it affects the neurovegetative functions and blood hampers. Cadmium is irreversibly bound by ferric and manganese oxides in soil and clay minerals that influence mobility [38].

Cd is one of the most phytotoxic metal pollutants because of its mobility, especially on soil with acidic soil $\mathrm{pH}$. The total bioactivity richness and diversity of microorganisms decrease with the increase of heavy metal concentrations because microorganisms differ in insensitivity towards heavy metal toxicity [39].

Alice landfill site operates as open dumping in which the waste is dumped and left open daily with soil. The management of landfills is not proper. It can be estimated to produce solid waste that contains several toxic substances such as POP's and heavy metals. The landfill site can cause harm the environment and put people's lives at high risk of contagious diseases. The landfill site lies along the water stream that the dumpsite passes to the next village. The heavy metals can leach off to groundwater and aquifers through the runoffs of soil erosion. The people who use these waters to irrigate their plants, even use them for drinking, can sometimes be affected by heavy metal pollution.

\section{Conclusion And Recommendations}


In this study, the soil from the landfill site contains high levels of heavy metal (specifically $\mathrm{Pb}, \mathrm{Hg}$, and $\mathrm{Cd}$ ) concentration compared to the control site's soil. Both sites have high metal concentrations, which exceeds the permissible limits from WHO.

Due to high metal concentration, nearby farmlands are at risk of pollution in their farm products with an accumulation of these metals. The concentration of heavy metals in this landfill site appears to cause a severe problem in the surrounding environment at the moment and later may cause more danger to human health and more damage to the environment.

This study's outcomes reveal that soil from landfill sites contains more heavy metals than the soil from unpolluted areas. The soil pollution by heavy metals led to poor soil health and quality, surface and groundwater pollution, and food contamination, resulting in a hazardous risk to human health. Therefore, this study's findings show the necessary need to monitor and manage soil pollution properly and combined working efforts from both the residing and municipality residents. This study commenced helping address the soil pollution problem due to the illegal disposal of waste to monitor waste at large garbage coming from communities. These results may have a significant role in helping the local authorities take severe actions for remediation processes. This report study can be an essential reference for guiding the policymakers to focus more on soil pollution caused by metals.

It is highly commended to provide proper attention to reduce the $\mathrm{Pb}$ and $\mathrm{Hg}$ pollution due to its negative influence on human health, affecting the central nervous systems and many other disorders. Soil bioremediation, phytoremediation, and hydrometallurgy to measure $\mathrm{Hg}$ and $\mathrm{Pb}$ should be introduced as a matter of urgency. Furthermore, government managers should encourage the use of sanitary landfills.

The obtained data provides necessary information for designing and managing waste disposal around the town, also provides information on the fate of vegetables and other crops cultivated on the dumpsites.

\section{Declarations}

I Maphuhla N.G, declare that this is my original work and it have never been submitted to any journal for publication. It is the first time this work submitted for publication.

\section{Availability of data and materials}

All data analyzed in this study was collected and put together by NG Maphuhla and is available in my device, it can be requested if needed.

Conflicts of Interest: The authors declare no conflict of interest.

Author Contributions: Conceptualization, N.G.M.; methodology, N.G.M.; software, N.G.M.; validation, N.G.M., F.B.L. and 0.O.O.; formal analysis, N.G.M.; investigation, N.G.M.; resources, N.G.M., and O.O.O.; data curation, N.G.M.; writing original draft preparation, N.G.M.; writing review and editing, N.G.M., and 
F.B.L.; visualization, N.G.M.; supervision, F.B.L. and O.O.0.; project administration; N.G.M.; funding acquisition, N.G.M. and 0.0.0. All authors have read and agreed to the published version of the manuscript.

Funding: This research was funded by the National Research Foundation (NRF) South Africa, Sasol Inzalo Foundation, and Govan Mbeki Research and Development Centre (GMRDC), University of Fort Hare.

\section{Acknowledgments}

The authors are grateful to Govan Mbeki Research and Development Centre (GMRDC), University of Fort Hare, Directorate of Research and Development, and University Research Foundation, Cape Peninsula University of Technology, NRF-Sasol Inzalo Foundation for financial support.

\section{References}

1. Bradl HB. Adsorption of heavy metal ions on soils and soils constituents. Journal of colloid and interface science. 2004 Sep 1;277(1):1-8.

2. Hashmi MZ, Yu C, Shen H, Duan D, Shen C, Lou L, Chen Y. Risk assessment of heavy metals pollution in agricultural soils of siling reservoir watershed in Zhejiang province, China. BioMed research international. 2013 Sep 15;2013.

3. Utobo EB, Tewari L. Soil enzymes as bioindicators of soil ecosystem status. Applied ecology and environmental research. 2015 Jan 1;13(1):147 - 69.

4. Mmolawa KB, Likuku AS, Gaboutloeloe GK. Assessment of heavy metal pollution in soils along major roadside areas in Botswana. African Journal of Environmental Science and Technology. 2011;5(3):186-96.

5. Ukpong EC, Antigha RE, Moses EO. Assessment of heavy metals content in soils and plants around waste dumpsites in Uyo Metropolis, Akwa Ibom State. The International Journal of Engineering and Science. 2013;2(7):75-86.

6. Zahra N, Butt YN, Nisa AU. Biological and Physiochemical Techniques for the Removal of Zinc from Drinking Water: A Review. Pakistan Journal of Analytical \& Environmental Chemistry. 2015 Jun 1;16(2):10.

7. Opaluwa OD, Aremu MO, Ogbo LO, Abiola KA, Odiba IE, Abubakar MM, Nweze NO. Heavy metal concentrations in soils, plant leaves and crops grown around dump sites in Lafia Metropolis, Nasarawa State, Nigeria. Advances in Applied Science Research. 2012;3(2):780-4.

8. Azeez JO, Hassan OA, Egunjobi PO. Soil contamination at dumpsites: implication of soil heavy metals distribution in municipal solid waste disposal system: a case study of Abeokuta, Southwestern Nigeria. Soil and Sediment Contamination. 2011 May 1;20(4):370 - 86.

9. Nda-Umar UI, Nathaniel GS, Mann A, Yisa J. Assessment of heavy metal species in some decomposed municipal solid wastes in Bida, Niger State, Nigeria. Adv Anal Chem. 2012; 2:6-9. 
10. Jaishankar M, Tseten T, Anbalagan N, Mathew BB, Beeregowda KN. Toxicity, mechanism, and health effects of some heavy metals. Interdisciplinary toxicology. 2014 Jun 1;7(2):60-72.

11. Abidemi 00, Onwordi CT. Environmental fate of heavy metals in soil of Ido-Osun waste dump site, Osogbo, Osun, Nigeria. American Journal of Environmental Protection. 2015;3(1):1-4.

12. Motsara MR, Roy RN. Guide to laboratory establishment for plant nutrient analysis. Rome: Food and Agriculture Organization of the United Nations; 2008.

13. Sullivan DM, Moore AD, Brewer LJ. Soil organic matter as a soil health indicator: Sampling, testing, and interpretation. Oregon State University Extension Service; 2019 Aug.

14. Parajuli PB, Duffy S. Evaluation of soil organic carbón and soil moisture content from agricultural fields in Mississippi. Open J. Soil Sci, 2013, 3:81.

15. Zhang $Y Y$, Wu W, Liu H. Factors affecting variations of soil $\mathrm{pH}$ in different horizons in hilly regions. Plos one. 2019 Jun 19;14(6): e0218563.

16. Ullman JL. Soil Salinity in Agricultural Systems: The Basics. Agricultural \& Biological Engineering University of Florida, 2013. (accessed in 21 April 2018.)

http://hos.ufl.edu/sites/default/files/faculty/gdliu/ullman.pdf

17. Brady NC, Weil RR, Weil RR. The nature and properties of soils. Upper Saddle River, NJ: Prentice Hall; 2008, pp. 662-710.

18. Verma JK, Sharma A, Paramanick KK. To evaluate the values of electrical conductivity and growth parameters of apple saplings in nursery fields. International Journal of Applied Sciences and Engineering Research. 2015;4(3):321-32.

19. Kekane SS, Chavan RP, Shinde DN, Patil CL, Sagar SS. A review on physico-chemical properties of soil. International Journal of Chemical Studies. 2015;3(4):29-32.

20. Morugán-Coronado A, García-Orenes F, Cerdà A. Changes in soil microbial activity and physicochemical properties in agricultural soils in Eastern Spain. Spanish Journal of Soil Science. 2015 Nov 9;5(3).

21. Addis W, Abebaw A. Analysis of selected physicochemical parameters of soils used for cultivation of garlic (Allium sativum L.). Science, Technology and Arts Research Journal. 2015 Feb 9;3(4):29-35.

22. Finster ME, Gray KA, Binns HJ. Lead levels of edibles grown in contaminated residential soils: a field survey. Science of the Total Environment. 2004 Mar 29;320(2-3):245-57.

23. Ekpete OA, Festus C. Heavy metal distribution in soil along Iwofe Rumuolumeni road. International Journal of Science and Technology. 2013;8(1):450-5.

24. Mohajer R, Salehi MH, Mohammadi J, Emami MH, Azarm T. The status of lead and cadmium in soils of high prevalence gastrointestinal cancer region of Isfahan. Journal of research in medical sciences: the official journal of Isfahan University of Medical Sciences. 2013 Mar;18(3):210.

25. Nordberg GF, Bernard A, Diamond GL, Duffus JH, Illing P, Nordberg M, Bergdahl IA, Jin T, Skerfving S. Risk assessment of effects of cadmium on human health (IUPAC Technical Report). Pure and Applied Chemistry. 2018 Mar 28;90(4):755-808. 
26. Sonmez S, Kaplan M, Sonmez NK, Kaya H, Uz I. High level of copper application to soil and leaves reduce the growth and yield of tomato plants. Scientia Agricola. 2006 Jun;63(3):213-8.

27. Obasi PN, Akudinobi BB. Potential health risk and levels of heavy metals in water resources of leadzinc mining communities of Abakaliki, southeast Nigeria. Applied Water Science. 2020 Jul;10(7):123.

28. Adegoke JA, Owoyokun TO, Amore IO. Open land dumping: an analysis of heavy metals concentration of an old lead-battery dumpsite. Pacific Journal of Science and Technology. 2009;10(2):592-5.

29. Anyalogbu Ernest AA, Anadi CC, Nweje-Anyalowu Paul C, Nnoli Matthew C. World Journal of Pharmaceutical and Life Sciences. World Journal of Pharmaceutical and Life Sciences, 2017, 3(9): 48-53.

30. Kamunda C, Mathuthu M, Madhuku M. Health risk assessment of heavy metals in soils from Witwatersrand Gold Mining Basin, South Africa. International Journal of Environmental Research and Public Health. 2016 Jul;13(7):663.

31. Fijałkowski K, Kacprzak M, Grobelak A, Placek A. The influence of selected soil parameters on the mobility of heavy metals in soils. Inżynieria i Ochrona środowiska. 2012; 15:81-92.

32. Amos-Tautua BM, Onigbinde AO, Ere D. Assessment of some heavy metals and physicochemical properties in surface soils of municipal open waste dumpsite in Yenagoa, Nigeria. African Journal of Environmental Science and Technology. 2014 Jan 14;8(1):41-7.

33. Salman SA, Zeid SA, Seleem EM, Abdel-Hafiz MA. Soil characterization and heavy metal pollution assessment in Orabi farms, El Obour, Egypt. Bulletin of the National Research Centre. 2019 Dec;43(1):1-3.

34. Salman SA, Zeid SA, Seleem EM, Abdel-Hafiz MA. Soil characterization and heavy metal pollution assessment in Orabi farms, El Obour, Egypt. Bulletin of the National Research Centre. 2019 Dec;43(1):1-3.

35. Demková L, Jezný T, Bobul'ská L. Assessment of soil heavy metal pollution in a former mining areabefore and after the end of mining activities. Soil and water Research. 2017 Oct 9;12(4):229-36.

36. He L, Hu W, Wang X, Liu Y, Jiang Y, Meng Y, Xiao Q, Guo X, Zhou Y, Bi Y, Lu Y. Analysis of Heavy Metal Contamination of Agricultural Soils and Related Effect on Population Health-A Case Study for East River Basin in China. International journal of environmental research and public health. 2020 Jan;17(6):1996.

37. Malkoc S, Yazıcı B, Savas Koparal A. Assessment of the levels of heavy metal pollution in roadside soils of Eskisehir, Turkey. Environmental toxicology and chemistry. 2010 Dec;29(12):2720-5.

38. Elekes CC. Assessment of historical heavy metal pollution of land in the proximity of industrial area of Targoviste, Romania. Environmental Risk Assessment of Soil Contamination. 2014 Mar 26:257.

39. Xie Y, Fan J, Zhu W, Amombo E, Lou Y, Chen L, Fu J. Effect of heavy metals pollution on soil microbial diversity and bermudagrass genetic variation. Frontiers in plant science. 2016 May 31; 7:755. 


\section{Figures}

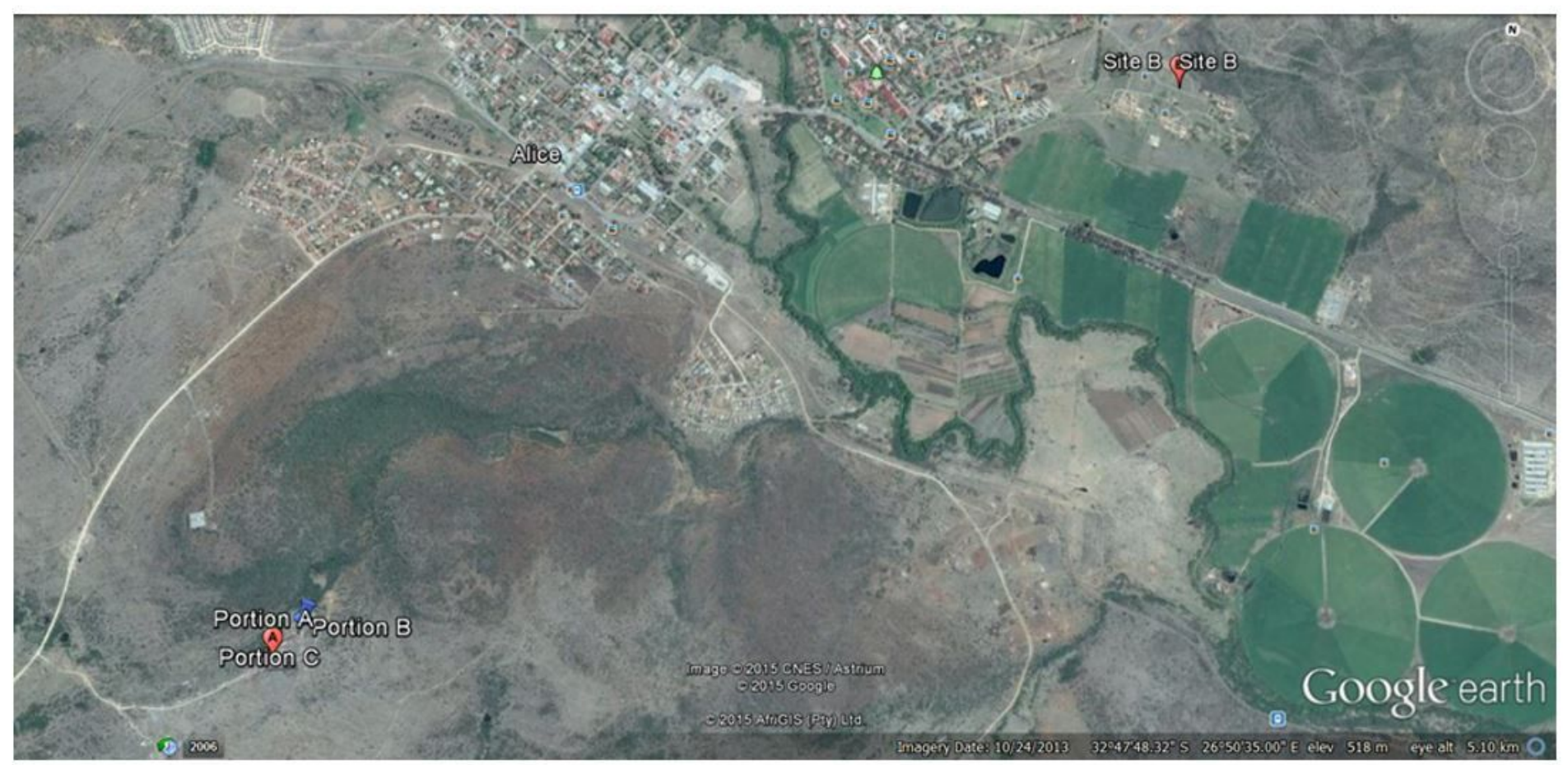

\section{Figure 1}

Map of Alice showing sampling sites Note: The designations employed and the presentation of the material on this map do not imply the expression of any opinion whatsoever on the part of Research Square concerning the legal status of any country, territory, city or area or of its authorities, or concerning the delimitation of its frontiers or boundaries. This map has been provided by the authors.

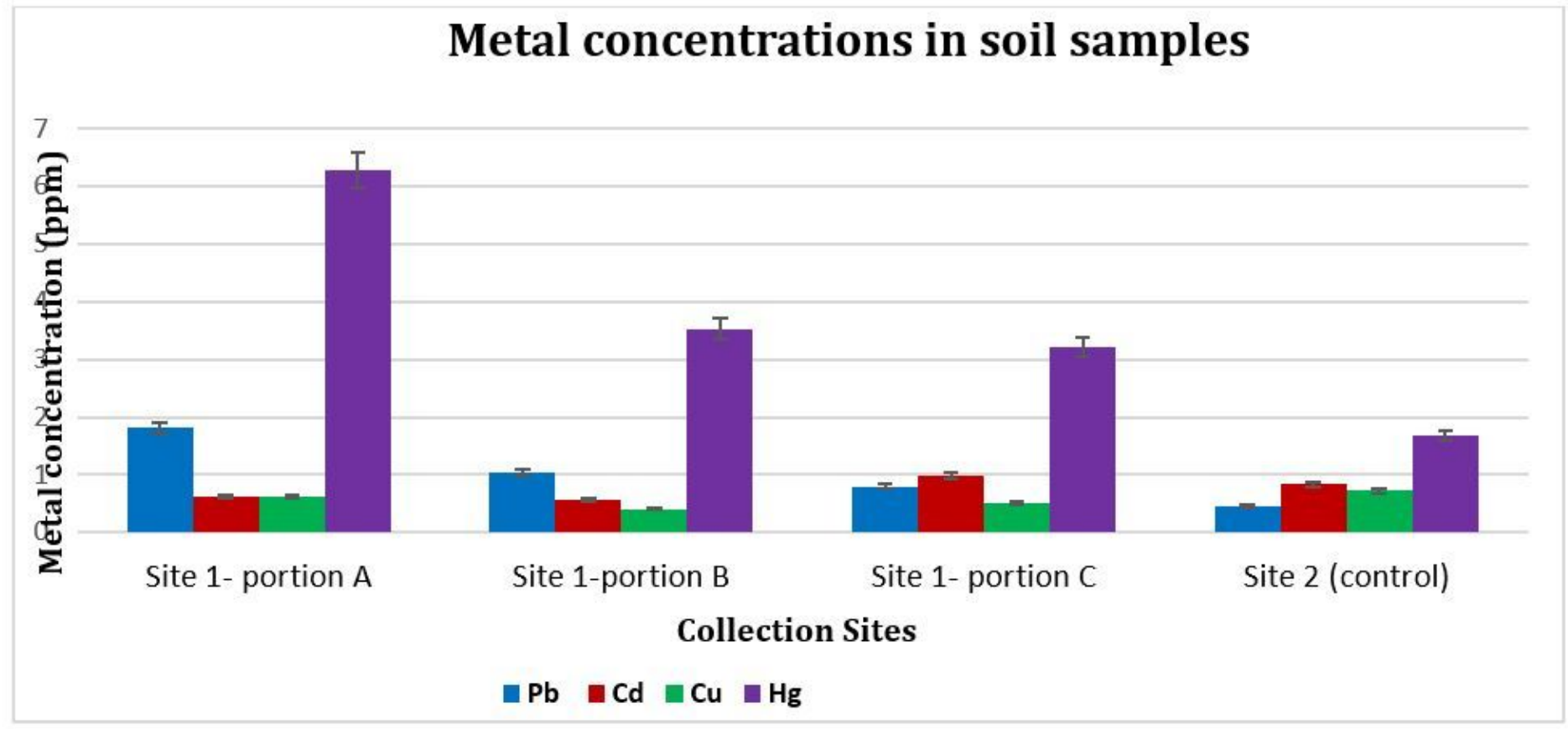


Figure 2

The heavy metals concentration in four sampling sites in ppm. 